\title{
CO2 EMISSIONS IN OWN MATERIALS FROM VERNACULAR ARCHITECTURE
}

\author{
C. Arguedas Garro ${ }^{1, *}$, B. Serrano Lanzarote ${ }^{1}$, M. Navarro Escudero ${ }^{2}$ \\ ${ }^{1}$ Universitat Politècnica de València, Valencia, Spain - cear3@doctor.upv.es, apserlan@mes.upv.es \\ ${ }^{2}$ Instituto Valenciano de la Edificación - mnavarro@five.es
}

Commission II - WG II/8

KEY WORDS: Materials, Embedded, Vernacular, Architecture, Energy, Emissions, Building

\begin{abstract}
:
The development of materials in the construction industry has a direct impact on greenhouse gas emissions - GHG, throughout the entire construction process from production, use and reuse. Being able to evaluate the energy embedded in the entire process is essential to establish criteria that allow the corresponding emissions to be calculated. The environmental impact of the building can be reversed through the appropriate use of materials referenced in the vernacular architecture if aspects of the life cycle characterized by standardized and regulated data on $\mathrm{CO}_{2}$ (Carbon dioxide) emissions are considered. This research has analyzed existing information on $\mathrm{CO}_{2}$ emissions of natural or traditional materials based on standardized data contained in 266 EPD (Environmental Product Declaration). It is important to generate this type of information so that it can be implemented in official construction databases. Specifically, 815 materials have been analyzed, based on their environmental impact, and a comparison of data -emission values, according to vernacular and non-vernacular materials- has also been developed, identifying on the importance of the use of traditional materials in vernacular architecture.
\end{abstract}

\section{INTRODUCTION}

\subsection{Environmental impact and vernacular materials}

Data on the $\mathrm{CO}_{2}$ emissions of a building and the global embedded energy on a construction depend on the design, knowledge and selection of materials, in relation to their durability and useful life.

To these aspects we must add the analysis of materials in old buildings in relation to their contemporary uses, such as stone and organic materials, which are still present in buildings and which generate technological innovations. The use of many of these materials has been recovered from the understanding of vernacular architecture and its durability, which allows for the management of a longer life of the constructions. The study of low-carbon vernacular materials brings sustainable innovation contributions to current buildings.

Part of the knowledge of low emission materials is being given in the field of research into the restoration and scientific reconstruction of old buildings, updating techniques and details of the behaviour of a material and its capacity for useful life and reuse, allowing professionals in architecture to study in detail the behaviour of traditional materials and durability. These evaluations of old buildings have provided details for establishing new technologies, in which the contribution of the material in low emission capacities and thermal efficiency behaviours is rescued.

Research on old buildings and the study of materials allow us to understand craft processes where energy demands are lower, which means that innovative technologies can establish building materials processes with control over carbon emissions; in this sense, building materials databases can contain within their indexing content materials used in restoration and old buildings that provide data on the reduction of built-in carbon.
Vernacular architecture legacy materials are of great architectural contribution and continue to occupy an important development in current constructions. This is the case of ceramics, wood, and stone materials, that have their importance in the production and research of environmental impact. The emissions data of the traditional materials are developed with the EPD (Environmental Product Declaration), and consists of a set of environmental data of the life cycle, provided by a company of a product or construction material, in accordance with the ISO $14025^{1}$.

The restoration of the Iberian City of Calafell in Tarragona (Catalonia) was based on research of the originary materials and the reconstruction of some spaces and buildings in the old city, original from the time and still present on the site (Belarte et al., 2001). The reconstruction team was in charge of investigating the original state of the city, studying the use of stone and organic materials, allowing the understanding of the building processes.

A part of the architectural complex of the Iberian city of Calafell was left in its original state, while another part was reconstructed. As mentioned, this was based on the understanding of the techniques and the use of materials based on organic compounds such as straw, clay, wood and stone, allowing the understanding of the dynamics of the thermal properties of these materials in the Iberian constructions of the 6th century $\mathrm{BC}$ in relation to the Mediterranean climate.

This type of restoration allows to study the thermal properties of materials and their possible use for energy efficiency, considering that the of old buildings were really decarbonised and useful today.

* Corresponding author

ISO: International Organization for Standardization. In the case of Spain, UNE-EN ISO; UNE, E. International Spanish Standards. 


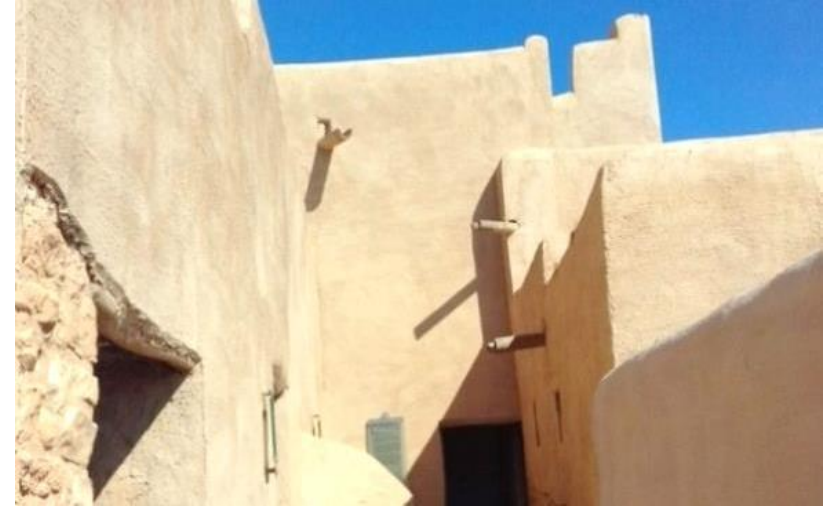

Figure 1. Iberian City-S.VI a.C., Calafell, Catalunya. Photo: César Arguedas.

This type of research has currently brought back the memory of low-carbon materials, which are being reintroduced in contemporary designs that seek to integrate technology with low-emission buildings and the use of natural or traditional materials with R\&D\&I projects ${ }^{2}$ and the development of EPDs $^{3}$. The continuity in the use of materials such as wood, stone, ceramics and some of their derivatives and the respective analyses on the environmental impact they generate, allow us to understand the usefulness of these materials, their low carbon emissions and their capacity to last.

\section{$1.2 \mathrm{CO}_{2}$ emissions from building materials}

In researching the content of the LEED (Leadership in Energy Environmental Design) certification library, embedded carbon is interpreted to represent the total emission potential of building materials, identified in the $\mathrm{CO}_{2}$ emissions generated in the following cycle: a) Building material manufacturing process, b) Use in construction, c) Material substitution, d) Material start and end of life of the material and treatment. The emissions corresponding to the extraction of the material, the transport and the manufacturing (cradle-to-gate) are incorporated into these stages of production, as one of the most impacting (Meneghelli, 2018).

Current carbon data for many materials consider aggregate values of emissions from raw materials, transport, and manufacturing; strictly speaking, this should be part of the sum of emissions that a material implies in its production and use. However, many databases of prices of building materials and data provided by the producers of the material themselves do not aggregate within their carbon emission value the data for the transport criteria. This suggests that on the one hand this allows each context to take data from a raw material before its placement and make estimates of aggregate values of carbon emissions due to the transport of the material; for this reason a data problem exists, i.e. between the aggregated data of the material emissions only in the factory and the material data in the factory including transport.

When emissions are declared in relation to the transport of the raw material to the factory during a material's production process, more specific data is provided in relation to energy dependence on fossil fuels; these details are indicated in most of the EPDs that comply with stage A1: Supply of raw materials, A2: Transport to the factory, A3: Manufacture, and are mandatory (UNE-EN ISO 14025, 2010), for which is essential to enter the data based on standards and certifications in the

2 R\&D\&I means: research and development, of new products.

3 EPDs: Environmental product declarations- EPD(s). construction price bases. The data on the $\mathrm{CO}_{2}$ emissions of a material, when it does not include in its calculation the transport of the raw materials to the factory, identifies a general data that does not specify the details of the A2 product stage. In this research, the data from stages A1-A3 are used, as they are the compulsory data in the EPDs, as well as the existing data in $100 \%$ of the EPDs produced.

Equation 1 shows the calculation criterion for carbon emissions when adding transport (Meneghelli, 2018), which would give more specific emissions data related to stage A2.

$$
E C_{A 4}=\sum_{i=1}^{n} E C \text { transp, } i=\sum_{i=1}^{n} M i \times d i \times \text { ECCtrasp }, i
$$

Equation 1. According to (Meneghelli, 2018, p. 231),

ECtransp, $i$ : Coal embedded in the transport of materials.

In Equation 1, it is important to identify the relationship between a building with an expected lifetime of 60 years, the building replacement process, recycling, and the distance of manufacture of the material in the sense of production and transport. It also involves the expected lifetimes of the building components, which determine the quantities of new materials and therefore the related emissions for material extraction, manufacture and transport to the construction site (Meneghelli, 2018).

\section{METHODOLOGY AND RESULTS}

\subsection{Environmental impact of materials in vernacular architecture}

Involving the criteria prior to those of the delegated regulation of the Commission (European Union -EU) No 244/2012 of the 12 January 2012 (Commission Delegated Regulation, 2012) and those of the Delphi method (García, Suárez, 2013); some essential points can be identified in the environmental impact of a building and in relation to the calculation of emissions:

a. The expected lifetime is between 60 and 70 years.

b. Conservation and maintenance range from 50 years.

c. Emissions from the manufacture of the material under factory conditions.

d. Emissions due to the demolition of the work.

e. Costs related to climate and maintenance.

f. Range of expected life of the material according to the intended use, based on a building life of 60 to 70 years, low: 0 to 10 years, medium: 10 to 30 , high: 30 to 40 years, length: 40 to 70 years, and more than 70 years.

g. Transport of the material: from the factory to the site, placement-assembly (production, useful life).

h. Range of energy demand during construction, costs of public or private energy consumption, daily expenditure during construction (Commission Delegated Regulation, 2012).

i. Data on emissions of vernacular materials and, in general, within a construction price base, which may vary according to their type, classified as:

- Traditional materials from industry (fossil fuels).

- Materials from the resident industry (relative impacts).

- Technological innovation (composites, smart, nano).

- Biological materials (low impact of emissions; innovation).

- Organic materials (materials in the vernacular architecture).

- Inorganic materials (long life).

- Stone materials (materials in the vernacular architecture).

- Rare materials (liquids, gas, solids, etc.).

- Acoustic thermal materials (vernacular, not vernacular). 


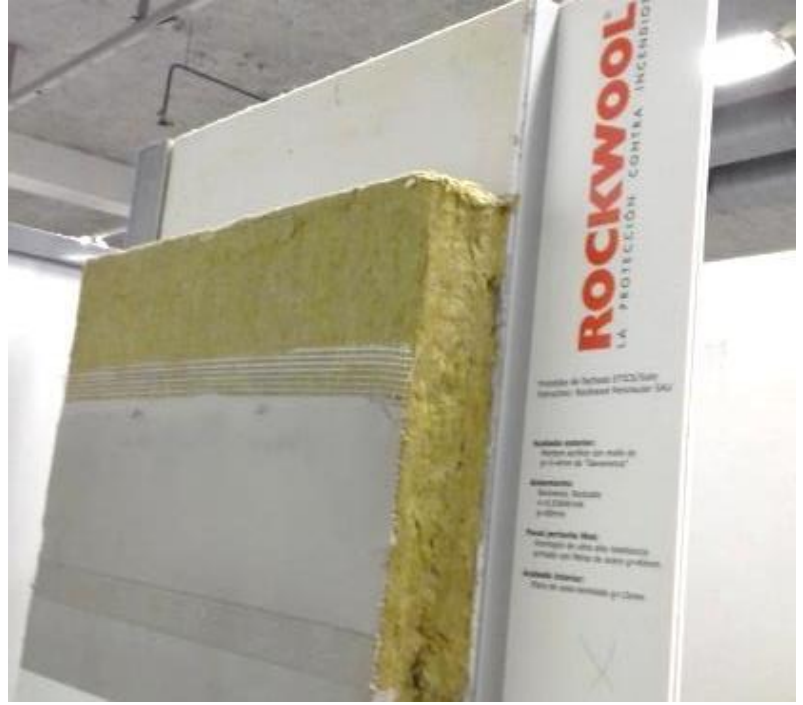

Figure 2. Panel, high embodied energy. Photo: César Arguedas.

The following is an example of a system based on acoustic thermal materials (vernacular, non-vernacular), using concrete with rock wool. In this case, rock wool has its origin in volcanic rock, and concrete in stone, sand, cement, both cases have traditional materials, but there are additional processes of great environmental impact and energy embebed in the production of the system - panel (Figure 2).

In prototype of a thermo-acoustic façade, Rockwool Peninsular -SAU (Figure 2), a panel developed from rock wool and concrete cladding is identified, whose industrial production process involves a set of materials adhered to the system, which implies a product with greater environmental impact due to all its components (fossil fuels).

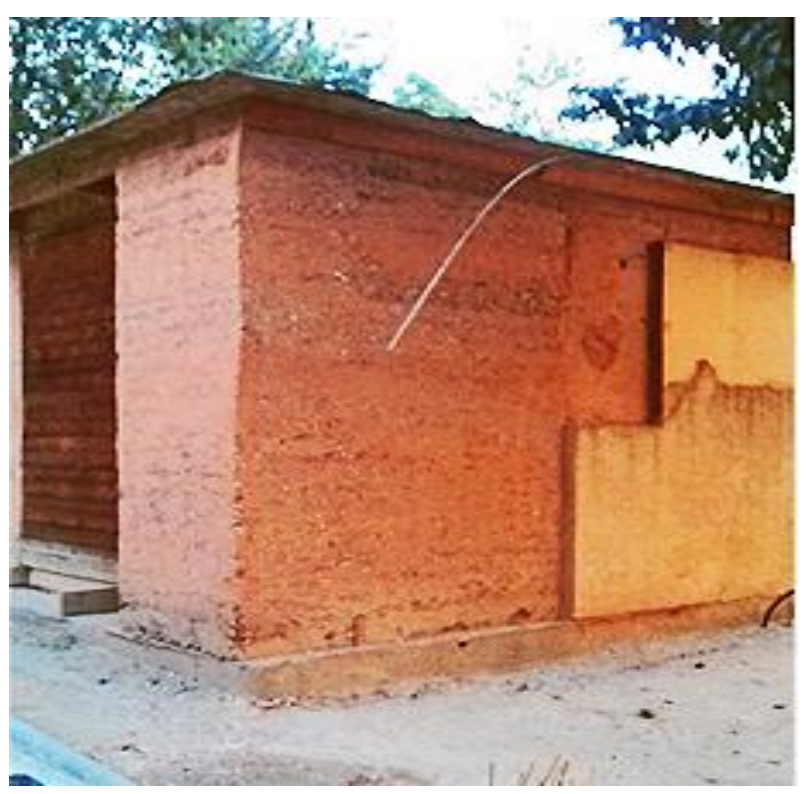

Figure 3. Earth-wood, low embodied energy. Photo: César Arguedas.

The S-Low House project is identified in this research as a benchmark for contemporary edification based on the recovery and use of traditional materials, in this case of rocks, organic with thermal capacity (Figure 3).
S-Low House by the architects Sandra Martín-Lara and Ángel Estévez, identifies an experimental building based on vernacular materials (organic, stone). Has walls of metered and compacted earth extracted from a site near Barcelona, with wood panels and shavings unified by means of a binder made with pressure and heat. A thermal insulation based on cellulose fibers was added, using a technique of wall structure with a sheet of wood, tongue-and-groove slats made of plywood, and in the upper part a slab of landscaped roof (Figure 3).

Both the facades and the building have a low impact of $\mathrm{CO} 2$ emissions, which allows the energy cost of each material to be analyzed. The construction processes were carried out with local raw materials and on site manual construction techniques were used; in this case the cubicle is $3.54 \mathrm{mx} 3.54 \mathrm{~m}$, with a height of $2.9 \mathrm{~m}$, with upper and lower slabs, some cladding was stabilized with clay and additive cement. The building is located on the South campus of the UPC, Barcelona School of Architecture - ETSAB (Bosch et al., 2013), (Figure 3).

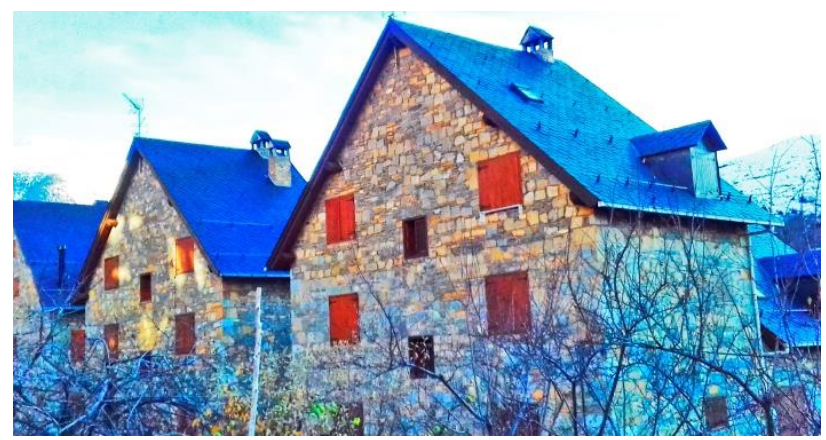

Figure 4. Stony, low embodied energy. Photo: César Arguedas.

The recent constructions in the Catalan Pyrenees area, expose the use of traditional materials, in this case of wood, rock and slate, these are built following the rules of use of materials related to the historical buildings of the region (Figure 4).

Recent habitational construction in the Pyrenees, Vall de Boi, Lleida, Catalonia, Spain, use of rock for façade and slate roof, secondary wooden structures, façade with local materials, of low environmental impact, new construction based in normative on the traditional systems referred to the Romanesque vernacular architecture catalan in Vall de Boi (Figure 4).

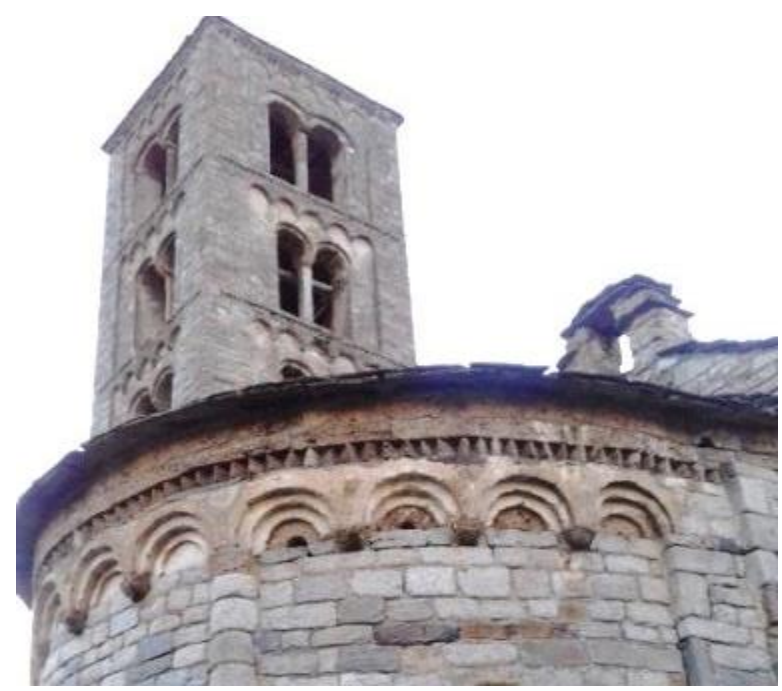

Figure 5. Romanesque, Sant Climent de Taüll year 1123 AD. Photo: César Arguedas. 
The Romanesque architecture of the Catalan Pyrenees shows a specific case of the use of traditional materials (organic materials, stone materials) and the capacity of durability, being constructions with more than 1000 years and adapted to the climate (Figure 5).

Romanesque church in the Pyrenees, Vall de Boi, Lleida, Catalonia, Spain (Figure 5), Medieval vernacular architecture, with the use of stone and wood materials, low environmental impact construction and passive strategies, carried out with manual processes and local materials. It is a reference point for new residential and tourist buildings in the Pyrenees region.

\subsection{Comparison of environmental impact data (ceramics, wood, stone, concrete, glass)}

The construction innovation industry is developing an accelerated patent route for use materials on building facades; many of these materials are based on technological research that aims to improve thermal capacity. Given that the industry specializes in the development of construction materials, both companies and R\&D\&I (research and development, of new products), have to identify the carbon emission data of the materials. This data must be contributed to the construction pricing bases, so that professionals establish a criterion of knowledge of the material and the cost of the material's $\mathrm{CO}_{2}$ emissions. This is an aspect that involves both traditional, vernacular, innovative materials and thermal systems composed of various materials.

The data on carbon emissions from materials corresponds to a technology industry that seeks to minimize the impact of global warming and a specific decision between producing high-cost materials due to high- emissions or low-cost materials due to low emissions. The materials of the vernacular architecture are used in sustainable construction; the development of EPD shows an increase in the production of traditional low-impact materials, but contrasts with a greater consumption of materials with high environmental impact in construction, identified in a large amount of EPD, of non-traditional materials, like concrete, steel, glass.

The environmental impact in construction has variables depending on the type of material, the relationship between life cycle durability and application, demonstrating that there are more suitable solutions, for example in the use of aluminum curtains and wooden curtains on windows. Both cases help to reduce the energy demand in the building, but the wooden curtains on the windows are more environmentally friendly than the aluminum curtains, after being analyzed, their lower risk to human health was shown due to their cycle of life and environmental impact, identifying a big difference between using wood or aluminum (Babaizadeh et al., 2015).

In the research of a comparative proposal in relation to the environmental impact of traditional and contemporary materials of the 20th century, a comparative analysis on the life cycle of some essential building materials such as wood, metals and concrete was carried out (Hanandeh et al., 2017).

The aspects related to their usefulness in Australia were identified in the research, based on a comparison between their life cycle behavior and their use. The study compared these essential materials in the structural aspects and the relationship of environmental impact, where it is observed that the use of wood has the best performance in life cycle terms, being a material originating from the vernacular architecture of great utility at present.
In the present research, natural materials and industrial materials have been studied, in relation to the construction products identified in the data of the Valencia Institute of Building-IVE (Base de Datos de Construcción, 2020), analyzing the relationship of the materials with the data of $\mathrm{CO}_{2}$ emissions published in the environmental product declarations EPD, according to the standards and ISOs (UNE-EN ISO 14025, 2010), (UNE, E. 15804, 2012), (UNE-EN 15804: 2012 + A1, 2014) ${ }^{4}$, or environmental declaration by means of a technical sheet of the material according to the company producing it or the environmental database for construction products, from the Eduardo Torroja Institute of Construction Sciences -IETCC (Opendap, 2013). The research has made it possible to obtain comparative data on emissions between materials.

The evaluation in this investigation, to identify the usefulness of the analyzed and qualified data of $\mathrm{CO}_{2}$ emissions in the 815 materials (Construction Database, 2020), was based on obtaining the following score:

A) Emissions data in compliance with ISO (UNE-EN ISO 14025, 2010), one point.

B) Emissions data in compliance with the standard (UNEEN 15804: $2012+$ A1, 2014), one point.

C) Data declared valid when publishing the EPD or information, one point.

Of the analyzed materials, 224 were identified with data on $\mathrm{CO}_{2}$ emissions, evaluated and classified as useful, obtaining the 3.00 points $(\mathrm{A}, \mathrm{B}, \mathrm{C})$.

This procedure established the selection criteria for the information with which the data were entered (Base de Datos de Construcción, 2020), having analyzed materials from the vernacular architecture and industrial materials (contemporaries). In this research, ceramics, wood, stone, concrete, steel, and glass were compared.

The analysis of the materials data identifies the production of EPD(s) in Spain that are valid in the European Union, with the aim of evidencing the industrial development of building materials and the trend towards materials that have evolved from vernacular architecture and non-traditional.

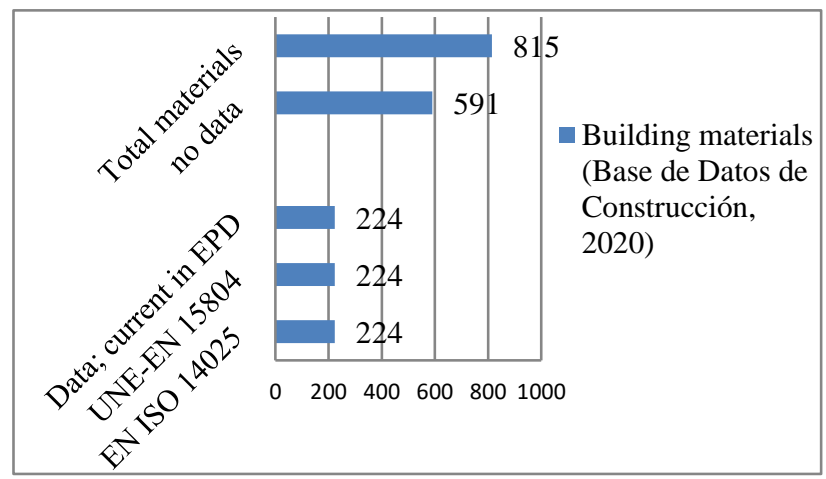

Figure 6. 815 materials were analyzed with 224 compiled $\mathrm{CO}_{2}$ data (Base de Datos de Construcción, 2020).

The information in the environmental declarations -EPD of products was decisive as it is data developed from compliance with ISO(s) and standards, in this case from the European Union (Figure 6).

\footnotetext{
${ }^{4}$ UNE-EN 15804: 2012 + A1:2014. A1 means: phase included.
} 
It can be identified that the most useful EPD information for the catalogue was that which was updated and produced according to the ISO and standards (UNE-EN ISO 14025, 2010), (UNE-EN 15804, 2012), (UNE-EN 15804 : 2012 + A1, 2014), (Figure 6).

The $\mathrm{CO}_{2}$ data analyzed and compiled refer to both materials from the vernacular architecture and industrial materials, demonstrating that the materials with the least environmental impact in the process of their productions by the companies have been those of traditional and organic origin, for example, sheep's wool (SHW) of animal origin, cotton (CO) of vegetal origin, hemp (HM) of vegetal origin, cellulose (CL) of vegetal origin, cork (ICB) of vegetal origin, coconut fiber ( CF) of vegetal origin, flax (FLX) of plant origin and wood chips (WF) of plant origin, however they have little EPD production, identifying 8 EPD related to them, showing that they are types of products with non-massive production in the industry of the materials, similar to the ceramic, wood and stone with scarce productions of EPD in Spain, (Figure 6).

\begin{tabular}{cccccc}
\hline 59 & & & & \\
& & 20 & 20 & 8 & 12 \\
\hline no data & $\begin{array}{c}\text { EN ISO UNE-EN } \\
14025\end{array}$ & $\begin{array}{c}\text { EPD } \\
\text { nemissions indicator }\end{array}$ & opendap \\
& &
\end{tabular}

Figure 7. Insulation materials.

From a total of 79 materials (P1 Productos y Materiales: Propiedades de aislantes térmicos para rehabilitación energética, 2011), no data was found on $\mathrm{CO}_{2}$ emissions according to the EPD of 59 cases, on the contrary, data was found on $\mathrm{CO}_{2}$ emissions according to the EPD in 20 cases, of which 8 correspond to thermals insulation with materials of natural and organic origin, demonstrating the low production in the market despite its low environmental impact (Figure 7).

Case of value of $\mathrm{CO}_{2}$ emissions from cellulose insulation: $\mathrm{A} 1$ : 7,16E-02 5 / A2: 2,10E-02 / A3: 6,49E-02, declared or functional unit in EPD: 1kg, stages [A1-A2- A3], (CAPEM Environmental Product Declaration Background Report Loose Fill Cellulose Insulation, 2018), (Figure 7).

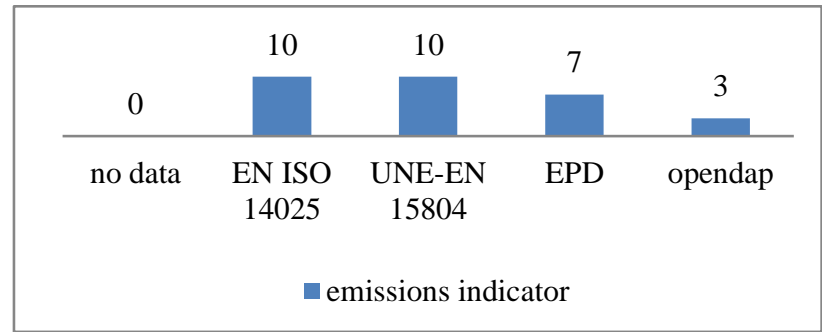

Figure 8. Ceramic category.

In the case of materials of vernacular ceramic origin, 7 EPDs were identified with $\mathrm{CO}_{2}$ emission data, demonstrating moderate production of the material with respect to the development of emission data, even when dealing with materials of low environmental impact (Figure 8).

\footnotetext{
${ }^{5}$ In an EPD, the E-00 data; E-01, E + 01, etc., mean: a large or small number in scientific format, with exponential notation, example; $1.2 \mathrm{E}+$ $10=1.2 \times 10^{10}$ (is 1.2 times 10 to the tenth power. $1.2 * 10^{\wedge}(10=$ 12000000000).
}

Value of $\mathrm{CO}_{2}$ emissions of a ceramic tile: A1: $1.5, \mathrm{~A} 2: 2.8 \mathrm{E}-01$, A3: $7.5 \mathrm{~kg} \mathrm{CO} 2 \mathrm{eq}$, (Global EDP 002-028, 2020), declared or functional unit in $1 \mathrm{~m} 2 \mathrm{EPD}$, stages [A1-A2-A3], (Global EDP 002-028, 2020), (Figure 8).

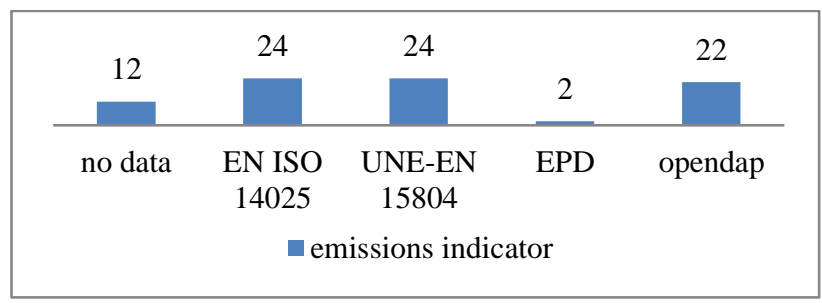

Figure 9. Wood category.

The case of wood, 2 EPDs were identified, as well as 24 data on types of wood products according to (UNE-EN ISO 14025, 2010), (UNE-EN 15804: 2012 + A1, 2014), which identifies wood production as a vernacular product, with data on low production of $\mathrm{CO}_{2}$ emissions, (Figure 9).

Value of $\mathrm{CO}_{2}$ emissions in the case of plywood: $1,89 \mathrm{E}+02 \mathrm{~kg}$ $\mathrm{CO}_{2}$ eq, declared or functional unit in EPD: $1 \mathrm{~m} 3$, stages [A1A2-A3], (S-P-00531, 2013), (Figure 9).

\begin{tabular}{|c|c|c|c|c|}
\hline 11 & 23 & 23 & 3 & 20 \\
\hline no data & $\begin{array}{c}\text { EN ISO } \\
14025\end{array}$ & $\begin{array}{c}\text { UNE-EN } \\
15804\end{array}$ & EPD & opendap \\
\hline
\end{tabular}

Figure 10. Stone and soil category.

Data set in relation to $\mathrm{CO}_{2}$ emissions from vernacular materials in the category of stone and soil, where 3 EPDs and 23 sources of product type data were found according to (UNE-EN ISO 14025, 2010), (UNE-EN 15804: 2012 + A1, 2014), indicating a higher production of GHG data in stone products (Figure 10).

Marble case $\mathrm{CO}_{2}$ emission value: $6.07 \mathrm{E}+01 \mathrm{~kg} \mathrm{CO} 2 \mathrm{eq}$, declared or functional unit in EPD: $1 \mathrm{t}$, stages [A1-A2-A3], (GlobalEPD: EN15804-001, 2017), (Figure 10).

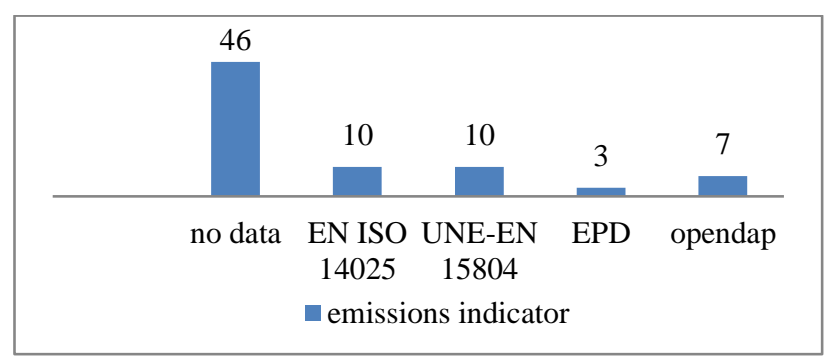

Figure 11. Concrete category.

In the case of concrete, 56 cases were identified, of which only 3 contained emission data according to the EPD added to 10 according to (UNE-EN ISO 14025, 2010), (UNE-EN 15804: $2012+\mathrm{A} 1$, 2014). It identifies that concrete is a contemporary material of great production but of relative production of data of regulated emissions (Figure 11). 
Value of $\mathrm{CO}_{2}$ emissions for reinforced concrete panels: $180 \mathrm{E}+$ $02 \mathrm{~kg} \mathrm{CO} 2 \mathrm{eq}$, declared or functional unit in EPD: $1000 \mathrm{~kg}$, stages [A1-A2-A3], (EN 16757: 2017 E, 2018), (Figure 11).

\begin{tabular}{ccccc|}
\hline 348 & 39 & 39 & 39 & 0 \\
\hline no data & $\begin{array}{c}\text { EN ISO } \\
14025\end{array}$ & $\begin{array}{c}\text { UNE-EN } \\
15804\end{array}$ & EPD & opendap \\
& & \\
& &
\end{tabular}

Figure 12. Semi-transparent glass components.

Of the 815 materials analyzed (Base de Datos de Construcción, 2020), those with the highest production in EPD data according to current regulations (UNE-EN ISO 14025, 2010) and ( UNEEN 15804: 2012 + A1, 2014), are semi-transparent (glass), which indicates a higher consumption of the product than the set of materials of natural and organic origin (Figure 12).

$\mathrm{CO}_{2}$ emission value for the safety glass box: $56.5 \mathrm{~kg} \mathrm{CO}_{2} \mathrm{eq}$, declared or functional unit in EPD: $1 \mathrm{~m} 2$, stages [A1-A2-A3], (S-P 00927, 2016), (Figure 12).

\begin{tabular}{|c|c|c|c|c|}
\hline 0 & 12 & 12 & 2 & 10 \\
\hline no data & $\begin{array}{c}\text { EN ISO } \\
14025\end{array}$ & $\begin{array}{c}\text { UNE-EN } \\
15804\end{array}$ & EPD & opendap \\
\hline
\end{tabular}

Figure 13. Metal category: steels.

Metal category identifies the emissions production data for 12 steels according to current regulations (UNE-EN ISO 14025, 2010), (UNE-EN 15804: $2012+\mathrm{A} 1,2014)$ and the development of 2 EPD (Figure 13).

Value of $\mathrm{CO}_{2}$ emissions in the case of steel: $510.66 \mathrm{Kg} \mathrm{CO}_{2} \mathrm{eq}$, declared or functional unit in EPD $1,000 \mathrm{~kg}$, stages [A1-A2A3], (GlobalEPD 001-001.01 rev. 3, 2019), (Figure 13).

\begin{tabular}{|ccc|}
\hline 77 & 189 & 266 \\
\hline $\begin{array}{c}\text { Material: } \\
\text { vernacular } \\
\text { architecture origin }\end{array}$ & $\begin{array}{c}\text { Material: non- } \\
\text { vernacular origin; } \\
\text { production s. XX }\end{array}$ & $\begin{array}{c}\text { Total analyzed } \\
\text { EPD of materials } \\
\text { nemissions indicator }\end{array}$ \\
\hline
\end{tabular}

Figure 14. EPD(s) analyzed and validity in Spain.

Of the data analyzed that includes EPDs of repeated materials with one or more statements made, it was identified that of 266 cases, 81 correspond to materials produced by companies whose origin refers to vernacular architecture and 185 cases correspond to materials produced whose origin is based on products with evolution in the 20th century (Figure 13). Stone and organic materials are those with the lowest greenhouse gas emissions - GHG, in the stages A1-A3, (Figure 14).

\begin{tabular}{|c|c|c|c|}
\hline $\begin{array}{l}\text { Type of } \\
\text { material }\end{array}$ & $\begin{array}{l}\text { Emissions } \\
\mathrm{CO}_{2}, \quad(\mathrm{~kg} \\
\mathrm{CO}_{2} \text { eq) }\end{array}$ & $\begin{array}{l}\text { Reference } \\
\text { EPD }\end{array}$ & $\begin{array}{l}\text { Regulations, in } \\
\text { force in the } \\
\text { declaration }\end{array}$ \\
\hline Wood & $\begin{array}{l}\text { 1,89E+02 } \\
\text { Phases } \\
\text { A1-A3 }\end{array}$ & $\begin{array}{l}\text { (S-P-00531, } \\
\text { 2013). }\end{array}$ & $\begin{array}{lr}\text { UNE-EN } & \text { ISO } \\
14025, & 2010), \\
\text { (UNE-EN } & 15804, \\
2012) & \\
\end{array}$ \\
\hline $\begin{array}{l}\text { Stony } \\
\text { marble }\end{array}$ & $\begin{array}{l}\text { 6,07E+01 } \\
\text { Phases } \\
\text { A1-A3 }\end{array}$ & $\begin{array}{l}\text { (Global } \\
\text { EPD: } \\
\text { EN15804- } \\
001,2017)^{6} .\end{array}$ & $\begin{array}{lr}\text { (UNE-EN } & \text { ISO } \\
14025, & 2010), \\
(\mathrm{UNE}-\mathrm{EN} & \\
15804: 2012+\mathrm{A} 1, \\
2014) .\end{array}$ \\
\hline $\begin{array}{l}\text { Reinforce } \\
\text { d concrete } \\
\text { panels }\end{array}$ & $\begin{array}{l}\text { 180E+02 } \\
\text { Phases } \\
\text { A1-A3 }\end{array}$ & $\begin{array}{l}(\mathrm{EN} \\
16757: 2017 \\
\mathrm{E}, 2018)\end{array}$ & $\begin{array}{l}\text { (UNE-EN } \\
14025, \\
\text { (UNE-EN } \\
15804: 2012+\mathrm{A} 1, \\
2014) .\end{array}$ \\
\hline Steel & $\begin{array}{l}510,66 \\
\text { Phases } \\
\text { A1-A3 }\end{array}$ & $\begin{array}{l}\text { (Global } \\
\text { EPD 001- } \\
001.01 \text { rev. } \\
03,2019)\end{array}$ & $\begin{array}{lr}\text { (UNE-EN } & \text { ISO } \\
14025, & 2010), \\
\text { (UNE-EN } & 15804, \\
2012) & \\
\end{array}$ \\
\hline
\end{tabular}

Table 1. Comparison of $\mathrm{CO}_{2}$ emission values (wood, concrete panels, stone-marble, steel).

The data on emissions declared in the EPD identify the variables of environmental impact between natural or traditional materials and industrial materials. In the case of wood, it turns out to be 95.23 times less pollutant in its production process than concrete-panels. In the case of the marble-stone material, it turns out to be 84.01 times less pollutant in its production process than steel. Concrete-panels are $98.11 \%$ more pollutant than wood, and steel is $98.81 \%$ more pollutant than stonemarble (Table 1).

With regards to concrete, the data for steel shows a greater environmental impact of GHG in its production process; as for stone material, the data for wood has shown to have a lower environmental impact of GHG. Both wood with $1.89 \mathrm{E}+02 \mathrm{~kg}$ $\mathrm{CO}_{2}$ eq (SP-00531, 2013), and ceramic tiling with A1: $1.5 \mathrm{~A} 2$ : 2.8E-01 A3: 7.5kg CO 2 eq, (Global EPD 002- 028, 2020), have a lower environmental impact (Table 1).

\subsection{Discussion}

The criteria for the selection of materials when establishing the aspects of the lifetime of the building and the choice of materials by thermal capacity can evolve in the aspect of technological innovation, since the consumption of materials with lower emissions is linked to the criterion of environmental impact. The production of materials from vernacular architecture offers a series of useful options for mitigating greenhouse gases -GHG in construction.

The selectivity of building materials is developed on the basis of a criterion of cost improvement through the reduction of GHG emissions, complying with a cycle that from its origin can depend on a sustainable energy matrix, in addition use traditional materials, which still exist on the market (in Spain), whit lower impact on stages A1-A2-A3, and transport local.

Not all types of products originating from vernacular architecture are supported by an investment by companies in the development of EPD, for example organic ones; more emissions $\mathrm{CO}_{2}$ data needs to be provided.

\footnotetext{
${ }^{6}$ GlobalEPD is: Program International EPD System.
} 


\section{CONCLUSIONS}

The macro-criteria used in this research define a logical procedure for the usefulness of the emissions data, when compiling the information for the construction databases (Base de Datos de Construcción, 2020), where the information is identified to know the environmental impact of a regulated product, and the difference between those of traditional, organic origin and those of higher GHG production. Of the sample of 815 materials indicated in the catalogue database, some 224 materials whit EPD, have been found on the market, which mainly comply with the ISO (UNE-EN ISO 14025, 2010) and with the norm (UNE-EN 15804: 2012), (UNE-EN 15804: 2012 $+\mathrm{A} 1,2014)$. According to the procedures for calculating $\mathrm{CO}_{2}$ emissions established in European Union regulations, of the total of the materials studied, some 224 comply with the standards.

In 815 materials analyzed and based on the content of the EPD, it is concluded that in order to compile the data of the materials in the construction price bases, they must comply with the information regulated according to the ISO (UNE-EN ISO $14025,2010)$ and with the standard (UNE-EN 15804, 2012) or (UNE-EN 15804: $2012+$ A1, 2014), where the EPDs provide current data, mainly in stage A1-A3 (from cradle to grave) of compulsory declaration, which includes the rest of stages $\mathrm{B} 1 /$ B2 / B3, B4, B5, B6, B7, C1 / C2 / C3, C4, D.

The developing of emissions GHG data makes it possible to identify the environmental impact in materials from the vernacular architecture. Materials from vernacular architecture allow research and development $-\mathrm{R} \& \mathrm{D}$, just like the practical construction to be carried out contributions to technological innovation, generating GWP ${ }^{7}$ impact data based on the analysis and use of materials, adapted to contemporary needs.

The reference to the life of a building with traditional materials is based on the historical sample of existing old buildings and the type of materials used. The investment in EPD production by the semi-transparent materials industry, such as glass, is higher than the investment in EPD produced in case of materials evolved of vernacular architecture. More data on the emissions of traditional or natural materials would facilitate a greater openness in the in architecture with a sustainable and low environmental impact design.

\section{REFERENCES}

AENOR, 2010. Etiquetas y declaraciones ambientales. Declaraciones ambientales tipo III. Principios y procedimientos (UNE-EN ISO 14025:2010). https://www.une.org/encuentra-tunorma/busca-tu-norma/norma?c=N0046196 (20 de abril de 2018)

AENOR, 2012. Sostenibilidad en la construcción. Declaraciones Ambientales de Producto. Reglas de Categoría de Productos básicas para productos de construcción (UNE, E. 15804: 2012). https://www.une.org/encuentra-tu-norma/busca-tu-norma/norma/ ?Tipo=N\&c=N0049704 (19 de diciembre de 2017)

AENOR, 2014. Sostenibilidad en la construcción. Declaraciones ambientales de producto. Reglas de categoría de producto básicas para productos de construcción (UNE-EN 15804:2012+A1:2014). https://www.une.org/encuentra-tu-norma/busca-tu-norma/ norma? $=$ N0052571 ( 15 de enero de 2020)

7 GWP: Global warming potential (GWP); EPDs identify the equivalent in $\mathrm{kgCO}_{2} \mathrm{eq}$, and in other greenhouse gases -GHG.
CPEM, 2018. Agrodome, [avniR] by cd2e and WeLOOP Loose fill cellulose insulation.

http://www.aislantesaislanat.es/wp-content/uploads/2018/02/

EnviromentalProductDeclaration.pdf (5 de diciembre de 2019)

Babaizadeh, H., Haghighi, N., Broun, R., Asadi, S., 2015. Life cycle assessment of common materials used for exterior window shadings in residential buildings. Procedia $\begin{array}{lll}\text { engineering, } & 118, & \text { 794-801. }\end{array}$ doi.org/10.1016/j.proeng.2015.08.516.

Belarte, M. C., Pou, J., Sanmartí, J. y Santacana, J. (eds), 2001. Tècniques constructives d'època ibèrica i experimentació arquitectònica a la Mediterrània. Actes de la I Reunió Internacional d'Arqueologia de Calafell (Calafell, 20, 21 i 22 de gener del 2000). Arqueomediterrània, 6, 244 p. Barcelona

Bosch-González, M., Navarro-Ezquerra, A., Poza, C., Allepuz, L., 2013. Proyecto Casa S-Low: construcción del prototipo y experiencia docente. En X CIATTI Congreso Internacional de Arquitectura con Tierra. Tradición e Innovación (pp. 1-10). Universidad de Valladolid, España.

European Cellulose Insulation Association (ECIA), 2018. Environmental Product Declaration. Loose fill cellulose insulation. http://www.aislantesaislanat.es/wp-content/uploads/2018/02/ EnviromentalProductDeclaration.pdf (16 de febrero de 2020)

Carabaño, R., Bedoya, C., Ruiz, D., 2014. Análisis de ciclo de vida de una nueva solución arquitectónica que mejora el rendimiento térmico de la envolvente del edificio: Fachada Natural Aljibe. Informes de la Construcción, 66(535), 034. doi.org/10.3989/ic.12.128.

EN 16757:2017 E. En Asociación Nacional de la Industrial de Prefabricado de Hormigón (ANDECE), 2018: Paneles de hormigón armado (norma UNE-EN 14992). http://andece.org/images/ADAP/andece_adap_panel2.pdf (21 de febrero de 2020)

EPD®: S-P-00501. En DANOSA, 2016. Declaración Ambiental de Producto: de la Plancha de Aislamiento Térmico de Espuma de Poliestireno Extruido (XPS) DANOPREN®. portal.danosa.com/danosa/CMSServlet?node=edp_danopren\&ln $\mathrm{g}=1 \&$ site $=1 \& \mathrm{dbg}=1$ ( 28 de diciembre de 2019)

EPD-PCE-2013256-IAA1-EN. En Institut Bauen und Umwelt e.V. (IBU), 2014: FOAMGLAS® T4+ Pittsburgh Corning Europe NV. http://www.kalcer.si/iz_foamglas/EPD_Foamglas_ISO_14025 __2014.pdf (5 de diciembre de 2019)

EPD-PUE-20140017-CBE1-ES. En PU Europe, Institut Bauen und Umwelt e.V. (IBU), 2014: Espuma de poliuretano proyectado aislante térmico (celdas cerradas; densidad $40 \quad \mathrm{~kg} / \mathrm{m} 3$ ). https://aislaconpoliuretano.com/wordpress/wp-content/uploads/ Declaracion-Ambiental-de-Producto_EPD-PUE-20140017CBE1-ES.pdf (10 de diciembre de 2019)

EU Commission., 2012. Commission Delegated Regulation (EU) No 244/2012 of 16 January 2012 Supplementing Directive 2010/31/EU of the European Parliament and of the Council on the Energy Performance of Buildings. Official Journal of the European Union, 55, 18-36.

García-Valdés, M., Suárez-Marín, M., 2013. El método Delphi para la consulta a expertos en la investigación científica. Revista Cubana de Salud Pública, 39(2), 253-267. 
Global EDP 002-028. En Azulejos Foset, S.L.U., 2020: Baldosas cerámicas. Azulejo (clasificación BIII según UNE-EN 14411: 2016). https://www.aenor.com/Producto_DAP_pdf/ GlobalEPD_002_028_ESP.pdf (28 de febrero de 2020)

GlobalEPD 001-001.01 rev. 03. En Siderúrgica Balboa, 2013: Productos largos de acero no aleado para construcción laminados en caliente procedentes de horno eléctrico: perfiles estructurales de uso general, barras y perfiles comerciales. https://www.aenor.com/Producto_DAP_pdf/GlobalEPD_001_0 03_01_r2_ESP.pdf (17 de marzo de 2020).

GlobalEPD: EN15804-001. En Levantina y Asociados de Minerales, SA, 2017: Tablas de mármol y caliza. https://www.aenor.com/Producto_DAP_pdf/GlobalEPD_EN15 804_001_ESP.pdf (13 de marzo de 2020)

GlobalEPD-RCP-007. En Grupo PUMA S.L., 2018: Sistema Traditerm EPS/EPS-G (SATE/ETICS). https://www.grupopuma.com/uploads/company/dap/DAPsistema-traditerm-eps-eps-g.pdf (28 de diciembre de 2019)

Instituto de Ciencias de la Construcción Eduardo Torroja (IETcc), 2013: Base de datos de carácter ambiental para productos de la construcción, Opendap. http://www.opendap.es/informacionambiental (1 de mayo de 2019)

Instituto Valenciano de la Edificación (IVE), 2020: Base de Datos de Construcción 2020. Anexo I: Aislantes térmicos y acústicos. Anexo II: Condiciones de cálculo de las características técnicas. https://www.five.es/productos/herramientas-on-line/ visualizador-2020/ ( 1 de marzo de 2020).

Instituto Valenciano de la Edificación (IVE), 2011: Cuadernos de Rehabilitación. P1 Productos y Materiales: Propiedades de aislantes térmicos para rehabilitación energética. http://www.caatvalencia.es/articulos/BV/Libros/VIR01934.pdf (05 de noviembre de 2017)

Lu, H. R., El Hanandeh, A., Gilbert, B. P., 2017: A comparative life cycle study of alternative materials for Australian multistorey apartment building frame constructions: Environmental and economic perspective. Journal of cleaner production, 166, 458-473. https://doi.org/10.1016/j.jclepro.2017.08.065.

Meneghelli, A., 2018: Whole-building embodied carbon of a North American LEED-certified library: Sensitivity analysis of the environmental impact of buildings materials. Building and Environment, 134, 230-241.

https://doi.org/10.1016/j.buildenv.2018.02.044.

RMT NITA, s.f.: Woll, Cotton. http://rmt-nita.es/ $(7$ de septiembre de 2019)

Rockwool. 2015: Aislamiento Térmico de Lana de Roca para Edificios. https://static.rockwool.com/globalassets/rockwooles/ herramientas/certificados/daps/ROCKWOOL_DAP_cap_es.pdf (28 de diciembre de 2019)

Serrano Lanzarote, B., García-Prieto Ruiz, A., Ortega Madrigal, 1., 2011: Catálogo de soluciones constructivas de Rehabilitación. Generalitat Valenciana / Conselleria de Medio Ambiente, Agua, Urbanismo y Vivienda, Instituto Valenciano de la Edificación.
S-P 00927. En SAINT-GOBAIN GLASS INDUSTRY, 2016: SGG SECURIT® on SGG PLANICLEAR / DIAMANT / PARSOL From $2 \mathrm{~mm}$ to $19 \mathrm{~mm}$ Toughened safety glass. https://gryphon4.environdec.com/system/data/files/6/12116/epd 927\%20Saint-Gobain\%20Securit\%202016\%20V.02.pdf (19 de marzo de 2020)

S-P-00273. En FINSA, 2017: Medium Density Fibreboards (MDF) and for Melamine faced medium density Fibreboards (MDF). https://gryphon4.environdec.com/system/data/files/6/9912/epd2 73_FINSA_MDF\%20and $\% 20$ melamine $\% 20$ faced $\% 20 \mathrm{MDF} \_20$ 18.pdf (20 de octubre de 2019)

S-P-00531. En Maderas de Llodio, S.A., 2013: Tableros Contrachapados Laudio Form/Car y Laudio PLY. http://www.clusterhabic.com/Wood/docs/MEDIO\%20AMBIEN TE_MDELLODIO_LAUDIO\%20FORM_PLY_EPD.pdf (29 de enero de 2020) 